\title{
The changing landscape of IS project failure: an examination of the key factors
}

\author{
1st Author \\ 1st author's affiliation \\ 1st line of address \\ 2nd line of address \\ Telephone number, incl. country code \\ 1st author's E-mail address
}

\begin{abstract}
Purpose - IS project failure has been a recurring problem for decades. This study examines the key factors that influence project failure and an analysis of the major areas that can have a significant impact on success. The study explores some of the key aspects that have an impact on project management performance from the practitioner perspective and discusses the problems faced by organizations in the closer integration of change and project management.

Design/methodology/approach - This study critically reviews the IS failure literature developing a synthesized view of the key issues and common reasons for projects to fail. The approach taken in this study is one that focuses on a number of key questions that pull together the relevant themes in this genre of research whilst highlighting many of the implications for practitioners and organizations alike.
\end{abstract}

Findings - Key questions remain on the underlying causes of instances of poor project management as an IS failure factor. The literature has omitted to develop a deeper analysis of the associations between failure factors and the potential causal relationships between these factors. The realization of project benefits relies on the success of both change and project management yet the formal integration of these two disciplines is constrained by separate standards bodies and an immature body of research.

Research limitations/implications - This study is limited by its theoretical nature lacking an empirical element to provide a deeper analysis of IS failure factors and their interrelationships. This specific area is a recommendation for future research, where causal relationships between failure factors could be developed via a mathematic based method such as Interpretive Structural Modeling (ISM).

Practical implications - With failure rates of IS projects still unacceptably high after decades of attempts to significantly change outcomes, a deeper analysis of this topic is required. The research gaps and recommendations for practitioners highlighted in this study have the potential to provide valuable contributions to this topic of research.

Originality/value - The intent of this study is to present a new perspective of this genre of IS research that develops the main arguments and gaps in the literature from the practitioner viewpoint.

Keywords - IS project failure, project management, failure factors,

Paper type - Research paper

\section{Introduction}

The last four decades have seen significant levels Information Systems (IS) project failure resulting in huge losses to governments and private organizations (Hughes et al. 2015, Dwivedi et al. 2015ab; 2013a). Although the trend in successful project delivery seems to be slowly improving from a historical low point of 29\% in 2004 to a more recent figure of 39\% (Standish Group 2013), well over half of IS projects are not delivered successfully. These figures suggest there is still much to do in the 
context of a better understanding of how failure occurs, what can be done to further improve project outcomes and the development of models and frameworks that can highlight potential areas of failure early in the lifecycle.

\begin{tabular}{|c|c|c|}
\hline $\begin{array}{l}\text { Methodological } \\
\text { Approach }\end{array}$ & Studies & Key Themes \\
\hline Review & $\begin{array}{l}\text { Al-Ahmad et al. (2009), Dwivedi et al. } \\
\text { (2013), Dwivedi et al. (2015), Hughes et al. } \\
\text { (2015), Nelson (2007), Nixon et al. (2012). }\end{array}$ & $\begin{array}{l}\text { - Poor project management is a common failure factor } \\
\text { - Poor management and communication skills } \\
\text { - Project too big to fail, exec lacking courage to stop project } \\
\text { - Exec bias toward more risky technology option } \\
\text { - Difficulties faced by project managers on complex projects. } \\
\text { - Organizations inability to be open about IS failure }\end{array}$ \\
\hline $\begin{array}{l}\text { Industry } \\
\text { Research }\end{array}$ & Standish Group (2013), Prosci (2012) & $\begin{array}{l}\text { - Large projects have a virtual zero chance of being successful. } \\
\text { - Poor project sponsorship is a key factor that leads to failure }\end{array}$ \\
\hline Case Studies & $\begin{array}{l}\text { Avison and Wilson (2002), Barker and } \\
\text { Frolick (2003), Beynon-Davies (1995), } \\
\text { Brown and Jones (1998), Flowers (1997), } \\
\text { Gauld, (2007),Hirschheim and } \\
\text { Newman (1988), Lehtinen et al. (2014), } \\
\text { McGrath (2002), Mitev (1996), } \\
\text { Newman and Sabherwal (1996) } \\
\text { Pan et al. (2008), Rob (2003), } \\
\text { Scott and Vessey (2000), } \\
\text { Verner and Abdullah (2012) }\end{array}$ & $\begin{array}{l}\text { - No feasibility undertaken } \\
\text { - Lack of PM methodology } \\
\text { - Failure is multi-dimensional with interconnected factors } \\
\text { - Assertion that organization put price before quality } \\
\text { - Software was incomplete and not stable } \\
\text { - Incomplete and inconsistent training. } \\
\text { - organizational and political complexities are the key reasons } \\
\text { for high failure rates in public sector projects }\end{array}$ \\
\hline $\begin{array}{l}\text { Empirical } \\
\text { Studies }\end{array}$ & $\begin{array}{l}\text { Brown and Jones (1998), Bussen and } \\
\text { Myers (1997), Conboy (2010), } \\
\text { Conway and Limayem (2011), } \\
\text { Emam and Koru (2008), } \\
\text { Ewusi-Mensah and Przasnyski (1995), } \\
\text { Fitzgerald and Russo (2005), } \\
\text { Jones (2004), Jones (2006), Keil et al. } \\
\text { (1998), Lemon et al. (2002), Nawi et al. } \\
\text { (2011), Philip et al. (2009),Pinto and } \\
\text { Mantel (1990), Sauer et al. (1997)Schmidt } \\
\text { et al. (2001), Standing et al. (2006),, Tukel } \\
\text { and Rom (1998), Verner et al (2008), } \\
\text { Wallace et al. (2004), Warne and Hart } \\
\text { (1997), Winklhofer (2001), Yeo (2002) }\end{array}$ & $\begin{array}{l}\text { - Over-reliance on an external contractor } \\
\text { - Elongated time-scales and impact on staff commitment. } \\
\text { - No effort made to fully understand what went wrong } \\
\text { - Lack of management commitment } \\
\text { - No effort made to find out what went wrong and learn from } \\
\text { past mistakes } \\
\text { - Lack of time devoted to PM based tasks } \\
\text { - Inaccurate estimating on large projects } \\
\text { - If organizations paid attention to EWS during first } 20 \% \text { of } \\
\text { project lifecycle, probability of successful outcomes is greatly } \\
\text { increased. } \\
\text { - Poor assessment and management of risks } \\
\text { - Project management and process failings were biggest } \\
\text { - Lack of top management commitment }\end{array}$ \\
\hline $\begin{array}{l}\text { Theoretical } \\
\text { Studies }\end{array}$ & $\begin{array}{l}\text { Bronte-Stuart (2003), Davis (2014) } \\
\text { Ewusi-Mensah (2003), } \\
\text { Fenech and Raffaele (2013), } \\
\text { Goulielmos (2005),Heeks (2002), Keider } \\
\text { (1974), Kerzner (2013), Lyytinen and } \\
\text { Hirschheim (1987), Nelson (2007),Pinto } \\
\text { and Mantel (1990),Sauer (1993),Ward and } \\
\text { Elvin (1999), Young (2005) }\end{array}$ & $\begin{array}{l}\text { - Failure linked to inability to deliver desired value } \\
\text { - Stakeholder support for system is critical } \\
\text { - Social aspects associated with of IS failure ignored } \\
\text { - Key to identify early stage threats to IS project } \\
\text { - High rates of failure in developing countries due to context } \\
\text { gaps and local actuality factors } \\
\text { - Project management seems to have an over reliance on task } \\
\text { based activities. } \\
\text { - Increasing range of complex issues affecting IS projects } \\
\text { - Top management support is the key critical factor. }\end{array}$ \\
\hline
\end{tabular}

Figure 1: Literature review categories

Figure 1 presents the key methodological approaches within the body of literature covering IS failure identifying: review studies, industrial and practitioner based research, case studies, empirical research and theoretical studies. This study includes the analysis of the body of literature from all of these categories of IS failure research. The classification of IS failure within the literature is multidimensional in nature (Pinto and Mantel 1990), demonstrating a distinct lack of consensus on an agreed set of criteria to define failure. Studies often analyze the classification of IS failure, proposing a framework as a mechanism or tool to assist with failure analysis and classification (Flowers 1997, 
Lyytinen and Hirschheim 1987, Sauer 1993,1997). Studies have reviewed the events surrounding a specific project within an organization (Beynon-Davies 1995, Gauld 2007, McGrath 2002) or group of projects (Jones 2004) providing useful insight from the perspective of understanding real life project failings and lessons learned from the project. Many of these types of study attempt to present a unique view on the analysis of failure and its determinants, presenting a theoretical approach to mitigate failure (Ewusi-Mensah 2003, Fenech and Raffaele 2013), often including a theoretical model to reinforce the direction of research (Cule et al. 2000) Goulielmos (2005),. Sections of the literature include studies that analyze multi-organizational data from a cross section of projects and industrial based studies that attempt to gain an understanding of trends (Prosci 2012, Standish Group 2013) from a statistical and survey perspective. This approach also includes studies that develop empirical data from interviewing stakeholders or conducting surveys of IS professionals (Cerpa and Verner 2009, Verner at el. 2008) either from a single or multi-organizational viewpoint. Some studies analyze single industrial sectors in a specific location or geographically dispersed organizations to gain a multilocation insight (Emam and Koru 2008, Ewusi-Mensah and Przasnyski 1995). Review based studies undertake an extensive literature review on IS failure to provide an informative overview and presentation of key themes and insights (Al-Ahmad and Al-Fagih 2009, Dwivedi et al. 2015b, Hughes et al. 2015). These studies generally present a taxonomy of IS failure factors or have sought to identify salient features of project failure and attempt to categorize and analyze the factors surrounding failure to present new insights to the research area (Dwivedi et al. 2013, Nelson 2007).

The available literature on IS failure is extensive, however, there are gaps in the literature and contextualizing new understandings of contributory factors and how they can influence IS project outcomes, justifies further research to reveal new insights and add further contribution. The continuing instances of IS project failure despite decades of research, necessitate ongoing academic review and analysis to further our understanding and direction of future research.

This study attempts to provide a fresh look at the IS project landscape with a specific emphasis on the changing views of failure and how it is managed within organizations. The study reviews the contribution of practitioner standards and methodologies highlighting issues of terminology, omissions of key guidance and the lack of an integration methodology between the key disciplines of change and project management. This practitioner viewpoint features throughout this study and is an attempt to provide greater relevance and understanding of the actuality of projects providing a reference point for further academic research.

The key questions that we pose in this study are:

- Is the analysis of how we measure and assess failure still relevant?

- What are the key factors that lead to project failure?

- Project management failure; why is this such a frequently cited factor given the increased level of industry-wide professionalism?

- Project success rates seem to be slowly improving, what are the key reasons for this change in outcomes?

- Is there a case for the closer integration of change and project management to better assure project success?

The study is structured as follows: section 2 - outlines the methodology used for the research, sections 3,4,5,6,7 are structured around the key set of questions outlined above. Section 8 discussion, Section 9 - recommendations for practitioners, section 10 - limitations of the research, Section 11 - concluding salient points. 


\section{Methodology}

In order to gain a full breadth of the subject area, the study has based its literature review on publications from journals, articles, conference proceedings and relevant books. Secondary data has been sourced from specific websites and press articles. It was the view of the authors that the nature of the topic dictated that a full selection of sources should be queried from high-ranking journals through to specific case study data from organization reviews and audits. An initial Scopus search using the terms: IS Failure, Information Systems failure, Information Technology Failure, IT Project Failure, Failure in IT, System Implementation Failure, Failure Factors in IS, Failure factors in Information Systems. No publication dates were used to restrict the search. The same terms were used to search the Web of Science database. Each of the listed publications were reviewed and categorized to highlight: methodological approach, research domain, key salient points, limitations of research, failure factors and their relationships. During this process the reference lists of key review papers and seminal publications were crosschecked with the search list and any relevant missing publications were added. Following a preliminary analysis of the studies, papers were selected based on their relevance, contribution to subject area, analysis and insight specific to the topic. Each of the publications included in the review were organized into the following categories of publication: review papers, empirical studies, theoretical studies and case studies. The literature review was structured around the analysis and categorization of study findings predominantly from the empirical and case study papers to identify the common factors and themes of IS failure. These topics were further analyzed and discussed in detail to present a full taxonomy of IS failure, highlighting of salient points, gaps in research and conclusions drawn from the review.

\section{Is the analysis of how we measure and assess failure still relevant?}

The literature has extensively classified and categorized the failure of IS projects to present a structure to the numerous incidents of poor project delivery (Flowers 1997, Lyytinen and Hirschheim 1987, Pinto and Mantel 1990, Sauer 1993). Historically, the literature has viewed project failure through the lens of specific success measures against: time, cost and quality - the so-called iron triangle (Sauer 1993). However, it is widely recognized that this approach fails to incorporate any stakeholder satisfaction criteria thereby relying solely on the technical or project management aspects of delivery (Dwivedi et al 2015a). Large-scale failures such as the French SNCF Socrate project and the London Ambulance Service Computer Aided Dispatch (LASCAD) system, highlight the catastrophic consequences of poor user engagement and failure to meet stakeholder expectations despite meeting many of the technical success measures (Beynon-Davies 1995, Fitzgerald and Russo 2005, McGrath 2002, Mitev 1996).

The classification and identification of project failure can often be a matter of perspective depending on the project organization and supply chain structure. The reality is that a supplier organization that delivers a project within an acceptable time frame against the contracted requirements, thereby delivering a profit for its shareholders, is likely to be judged on project profitability not stakeholder satisfaction. The same project may be seen as a failure by its stakeholders as levels of adoption and benefit realization, fall short of expectations - it is a question of perspective and judgment highlighting that success and failure cannot be judged on one measure but must be assessed based on several criteria. (Dwivedi et al. 2015b, Pinto and Mantel 1990).

The widely cited categorization of IS failure as presented by Lyytinen and Hirschheim (1987) questions the project failure literature highlighting that existing research has focused on an unarticulated failure concept. The study presented the three traditional categories of failure from the literature and presented a new fourth category titled expectation failure:

- Correspondence failure - system not meeting its objectives 
- Process failure - system not delivered or delivered but failed to meet defined criteria

- Interaction failure - system not adopted by stakeholders, benefits not realized

- Expectation failure - system not meeting needs and expectations of stakeholder groups

Studies have highlighted that many projects have demonstrated poor quality requirements specification and conflicting objectives resulting in significant difficulties in contextualizing correspondence failure (Cooper and Swanson 1979, March and Olsen 1977). Sauer (1993) criticized expectation failure highlighting that some instances of stakeholder expectation are more reasonable than others, intention is ignored and potential differential stakeholder capacity is not taken into account (Sauer 1993).

Industrial based studies such as the extensively cited CHAOS Manifesto (Standish Group 2013) defines a category of challenged or impaired to define a project that has not suffered complete failure but was delivered late, over budget or failed to deliver the required levels of functionality. The report defines failure as projects that are abandoned prior to delivery or completed but not used, and defines project success as those projects that are delivered on time, on budget in adherence to requirements. Although the CHAOS approach has not received universal academic acceptance (Emam and Koru 2008, Glass 2005) its categories of project failure have been referenced throughout the literature. However, the categories are simplistic when compared to other studies (Lyytinen and Hirschheim (1987) and the definitions fail to include realization of benefits and stakeholder adoption criteria that can have a significant impact on project outcomes especially when assessed after the point of implementation. Measuring success at the point of system delivery before a new system and working practices are fully adopted by stakeholders, is likely to yield a different result than if this exercise was performed in the short to medium term when a more clearer picture has evolved (Hughes et al. 2015).

Sauer (1993) articulated an argument that an IS should be viewed as the product of a coalition of stakeholders and hypothesized that a project should not be categorized as a failure whilst stakeholder support exists for the system. This viewpoint was extended to the development a triangle of dependencies where the project organization, the system and its supporters are interrelated in the support and serving of each other (Sauer 1993). The framework highlighted in Hughes et al. (2015) extends the triangle of dependencies as set out in Sauer (1993) and is characterized as two time-bound segments: project implementation and post implementation. This represents the changed structure of the project and change organization after delivery of the system and the subsequent change in the bounds of support. The components of the model are:

1. Change-the changes to the users day to day processes and working practices due to the IS project and implementation,

2. System-the delivered IS that will realize benefits to the stakeholders and organization,

3. Change and project organization-temporary structure established to implement the project and deliver changes to the organization,

4. Stakeholder-the users, supporters and wider groups affected by the system,

5. Executive/Sponsor - the nominated senior manager or executive tasked with owning the vision of the project and driving the project forward to completion.

The Hughes et al. (2015) framework highlights the distinction between the project and post project periods and how failure can result when support is withdrawn from the executive and stakeholder groups highlighting the importance of driving benefit realization after the project has been delivered.

Projects have been categorized as suboptimal, abandoned or partially abandoned (Ewusi-Mensah 2003, Flowers 1997) and studies have highlighted that the categorization of failure is often subjective and should not be judged on one single measure (Dwivedi et al. 2015ab, Pinto and Mantel 1990). The frameworks developed by Lyytinen and Hirschheim (1987) and Sauer (1993) provide insight into the 
process of how project failure should be categorized but the literature lacks consistency in this area with no widely accepted one size fits all model to measure project outcomes (Pinto and Mantel 1990).

The practitioners perspective on IS project failure is largely governed by the criteria set out in widely used standards and methods such as the Project Management Body of Knowledge (PMBoK) and Projects in Controlled Environments (PRINCE2) as defined in PMI (2013) and OGC (2013) respectively. The practitioner guidance identifies the requirement for the definition of acceptance or success criteria as a mechanism for ensuring that the delivered system meets the stated requirements. Success criteria are the list of principles and standards used to determine or judge project success (Ika 2009) and should be formally agreed with the key stakeholders during the early stages of the project to avoid any acceptance issues during implementation. The practitioner guidance uses the terms product and project acceptance criteria to describe success criteria at the deliverable and overall project levels (OGC Group 2013, PMI 2013). Simplistically, a reasoned practitioner argument could be articulated that if a project is delivered in full compliance with the agreed success criteria, then how could the project be viewed as a failure? Of course, the answer to this question depends on the set of criteria that has been defined and how they have been interpreted. Furthermore, in circumstances where stakeholders withdraw support for the system (Sauer 1993) despite the project adhering to its acceptance criteria, it is likely to be categorized as a failure as the levels of adoption may be such that many of the defined benefits are not realized. This argument is pursued in a number of publications that have analyzed the success and failure of projects through the separate lens of project and project management perspectives (Cooke-Davies 2002, de Wit 1988, Baccarini 1999) highlighting that the two are quite different. The basic implicit hypotheses within each of these studies is one that views project management success (time, cost and quality criteria) and project success (the successful delivery of the project objectives) as very separate drivers within a project where the failure of one would not necessarily result in the failure of the other.

It is widely recognized in the literature that the historical perspective of measuring and categorizing failure via time cost and quality criteria, is not a sound basis for analysis as clearly the stakeholder satisfaction elements are omitted. This is best illustrated within the case studies of significant project failures (Beynon-Davies 1995, Fitzgerald and Russo 2005, McGrath 2002, Mitev 1996) that highlight the consequences of not tackling many of the change management factors that can address stakeholder resistance and adoption of the new system. But if we ignore the time, cost and quality criteria and view the project from a different perspective where stakeholders wholeheartedly embrace a new system but the organization incurs cost overruns of $\$ \mathrm{~m}$ 's, should the project be viewed as a failure? If the inability of an organization to realize the defined project benefits is included within the categorization of project failure, this provides another measure, but in reality, project benefits can be realized months or even years after system delivery (PMI 2013). Therefore, assessing and categorizing project failure at the implementation or delivery stage could be premature as benefits and longer-term stakeholder satisfaction may only be realized in the longer term. The perspective viewpoint is crucial in the context of measuring and categorizing project failure, in that different stakeholder types could have vastly differing views on the subject. Further study is required to develop a clearer empirically based view on the measurement and categorizing of IS project failure to incorporate: time cost and quality factors, stakeholder satisfaction based measures and both short and longer term benefits realization factors to develop a more complete measurement.

\section{What are the key factors that lead to project failure?}

IS project failure has a wide spectrum of root causes and interrelated factors. The literature has identified a number of key groupings of failure factors that can be shown to cover many of the key causes of IS project failure. These factors are discussed below: 


\section{Factors relating to Poor Change Management and User Resistance}

A frequently cited definition of Change Management is: "the application of a structured process and set of tools for leading the people side of change to achieve a desired outcome" (Prosci 2012, p.88). In the context of IS projects, this entails looking beyond the traditional iron triangle of deliverables and actively engaging users in the process of change, to realize the full benefits of the project. Industry based studies have identified that organizations incorporating good change management practices can increase the probability of successful change by a factor of four (CMI 2013).

Aspects of change management and high levels of user resistance are referenced in a number of studies as root causes of project failure. (Barker and Frolick 2003, Fitzgerald and Russo 2005, Hirschheim and Newman 1988, Keil et al. 1998, McGrath 2002, Mitev 1996, Pan et al. 2008, Scott and Vessey 2000). Many projects have suffered the consequences of not investing enough time and resources in the people side of projects highlighting: no change management methodology was implemented, failure to involve users within the early stage of the project, inadequate communication of change processes, poor management of user resistance within the organization and over emphasis of the technical aspects of project delivery (Beynon-Davies 1995, Brown and Jones 1998, Fitzgerald and Russo 2005, Gauld 2007, McGrath 2002). The failed SNCF Socrate project as outlined by Mitev (1996) highlighted the lack of user engagement and aspects of poor change management as key factors. Other large public sector project failures such as those outlined in Warne and Hart (1997) and Winklhofer (2001) highlight the impact of organizational conflicts and inability of project management to appreciate many of the social and political aspects of organizational change (Hirschheim and Newman 1988).

The implications of failing to adequately cater for the needs of stakeholders, has been referenced within historical studies as far back as 1970s (Lucas 1975). Historically, very few organizations identified, planned and managed business change with many projects instigating change management during the later stages of the project lifecycle (Bartis and Mitev 2008, Klaus and Blanton 2010, Ward and Elvin 1999). Empirical studies that have surveyed aspects of failure from the perspective of project managers (Attarzadeh and Ow 2008, Keil at al 1998, Lemon et al. 2002, Schmidt at al. 2001, Standing et al. 2006, Yeo 2002) demonstrate that failing to manage user resistance and formally manage change issues, are key contributory factors in failed projects.

The IS failure literature that references change management factors tends to provide scant details of the approach used, whether any change or project methodology or guidance was followed or where the organization is positioned in the context of change management maturity. The net effect of this potential gap in the research is an inability to fully understand if the change management related failings are cultural, methodological or the direct result of leadership and organizational issues. Organizations that engender a culture within the organization that is receptive to change resulting in active stakeholder engagement early in the project lifecycle, are more likely to demonstrate an effective resistance management process throughout the project (PMI 2013). Managing the process of successful change within an organization is extremely difficult, requiring the adoption of a core competency and methodological approach that requires the involvement of employees throughout the organization to realize successful sustained outcomes (Buchanan et al. 2005, Burnes 2005, Pettigrew and Whipp 1993).

\section{Poor Requirements Management}

The formal definition, configuration and control of project requirements are key aspects of successful project delivery. However, the literature has identified numerous projects where factors such as: misunderstanding and changes in requirements (Emam and Koru 2008, Keil et al 1998, Schmidt et al. 
2001), inadequate and unclear requirements (Bussen and Myers 1997, Nawi et al. 2011, Pan et al. 2008) and failure from scope creep as a direct result of not managing requirements effectively (Bussen and Myers 1997, Nawi et al. 2011, Pan et al. 2008, Rob 2003, Standing et al. 2006, Verner and Abdullah 2012). Projects that have relied upon the experience and expertise of external consultant organizations to expedite the requirements gathering process can be problematic. Studies have identified instances where stakeholders have not understood the technical language used by the consultants or the process followed to illicit requirements and agree fundamental design aspects (Brown and Jones 1998).

Managing the requirements process for large, long lead-time projects is especially difficult as the realities of defining an up-front detailed set of requirements for such complex systems become apparent all too clearly later in the lifecycle (Bussen and Myers 1997, Nawi et al. 2011, Pan et al. (2008). Business process change, requirements evolve over time, business strategy may change direction to fit market needs. All these things can make an IS project that seemed strategic at the onset, evolve into an expensive irrelevance. Modern procurement rules for large projects seem to reinforce the need for a fixed price implementation where the requirements are formally defined in the absence of a full and complete understanding of business needs. Studies have shown the benefits of a more agile approach to projects where an iterative approach to requirements and development is adopted (Standish 2013). However, the benefits and potential of applying these types of approaches to large and complex projects has yet to be tested.

\section{Poor Project Management and Project Planning}

IS failure studies have identified that poor project management and planning issues are key contributory factors in the failure of projects (Emam and Koru 2008, Jones 2004, Keil et al. 1998, Standing et al. 2006, Verner et al. 2008, Yeo 2002). Large projects, especially those in the public and health sectors that are not planned or managed effectively and those that are managed by an inexperienced project manager, have a significant risk of failure (Gauld 2007, Nawi et al. 2011, Pan et al. 2008, Philip et al. 2009).

Although referencing project management as a key factor, the literature does not seem to provide the level of detail to ascertain if the failings are methodology based, specific failings due to a lack of skills and experience or whether contributory factors led to the project management related failure. The analysis of project management standards and methodologies and their suitability for specific genres of IS projects has yet to be fully explored within the literature. The taxonomy of root causes of IS failure as presented by Al-Ahmad and Al-Fagih (2009) highlighted that many of the symptoms of IS failure can be aligned with failings of project management, but the research omitted to expand on the underlying assertions. Avots (1969) identified a lack of fit for purpose methodology for the project management failings but the study includes non IS genre projects. Avison and Wilson (2002) referenced the lack of a formal development methodology and poor controls but does not highlight if the project manager was at fault in not implementing these or if the organization did not prescribe the use of a methodology. The IS failure literature has generally omitted to indicate whether a specific project management methodology was applied on a failed project (Barker and Frolick 2003, Bartis and Mitev 2008, Hirschheim and Newman 1988, Lehtinen et al. 2014, Mitev 1996, Pan et al. 2008). Some studies either hint that a project methodology existed or that it was not implemented ineffectively (Gauld 2007, Newman and Sabherwal 1996, Verner and Abdullah 2012). Studies have highlighted that the adoption of a project management method is no guarantee of success (Beynon-Davies 1995, Scott and Vessey 2000) and that the management approach, style and ability of the project manager to deal with the diverse stakeholder interests and fast changing technologies are all key factors for successful outcomes (Sauser et al. 2009, Söderlund 2011). 


\section{Risk and Budget Management Failings}

The impact of not managing risk and project budgets effectively within projects has featured in many empirical studies surveying the experiences of practitioners and organizations (Jones 2004, Tukel and Rom 1998, Verner et al. 2008, Wallace et al. 2004). Issues such as: not assessing risks effectively, poor risk assessment and control, inaccurate estimation, poor budget management all feature as contributory factors in the failure of projects (Jones 2004, Keil et al. 1998, Pan et al. 2008). Studies have emphasized the lack of focus in the literature on budget management issues and their contribution to project failure highlighting how a culture of poor cost control and budget deviations are key factors in the failure of projects (Conboy 2010).

\section{Poor Executive Support, Sponsorship and Inadequate Management Structure}

Support for a project from the organizations top management is fundamental for successful outcomes with studies highlighting that the effectiveness of the sponsor is one of the strongest predictors of success or failure (Nixon 2012, Prosci 2012, Young 2005). Studies surveying the experiences of practitioners have emphasized instances where project have suffered due to executives lacking engagement with the project, ineffective sponsorship and overall lack of commitment from senior management (Emam and Koru 2008, Keil et al 1998, Lemon et al. 2002, Schmidt et al. 2001, Standing et al. 2006). The abandoned IS project at Gardenco - a New Zealand manufacturing company, highlighted the significant problems faced by the project due to the absence of an executive sponsor and lack of support from the board (Busssen and Myers 1997). The collapse of One-Tel in 2001 highlighted the impact of a complete lack of formal management structure and its negative effects on the project (Avison and Wilson 2002). Ineffective executive leadership and poor project sponsorship were key reasons for failure in the ERP implementation as outlined by Pan et al. (2008) and the Health Information Systems (HIS) project as studied by Gauld (2007).

\section{Project Too Large and Complex}

Large and complex IS projects have a dismal record of successful delivery with industry wide studies highlighting that this genre of project is more likely to fail outright than less complex, smaller projects. Studies have indicated that large projects have virtually a zero chance of success (Standish Group 2013). Aspects of the literature that have reviewed large IS project failures have identified some of the classic large project problems: excessive complexity, poor change management, stakeholders unable to understand the complex system, poor governance, high levels of complexity and integration (Gauld 2007, Jones 2004, Jones 2006, Mitev 1996, Nawi et al. 2011, Verner and Abdullah 2012). Large-scale strategic ERP failures such as those outlined in Barker and Frolick (2003) and Pan et al. (2008) indicate the significant problems delivering these types of projects and perhaps indicate that due to their complexity, failure at some level is inevitable (Scott and Vessey 2000).

It is not clear from the literature if project scale and complexity are by themselves key factors or due to projects being large and complex, that additional risk factors materialize necessitating that perhaps the project should be managed differently (Jones 2006). However, studies that have analyzed a range of large IS project failure case histories (Nelson 2007), highlight that other than size, most large project failures do not seem to have many common factors. Studies have theorized as to whether large projects should ever be initiated, as the likelihood of a successful outcome is so remote (Standish Group 2013). Senior management can perhaps mitigate some of the key factors surrounding large 
project failures by breaking-up large projects into a number of individual smaller projects, each structured to deliver individual capability and contribute to the overall benefits of the portfolio of projects. However, without formal controls, structure and application of suitable standards and methodology, problems are likely to remain. Project sponsors and senior management can often exhibit blind faith that success will be achieved as large amounts of money, resource and corporate reputations are at stake on large projects. Often many of the early warning signs are not acted upon with project staff being pressurized to ignore many of the key project fundamentals that form the basis of modern standards and methodologies (Kerzner 2013).

\section{Poor Contractor and Stakeholder Relationship}

Organizations that choose not to develop an IS in-house, will invariably use the services of a contracted entity to build and deliver the system. The foundations for an effective working relationship need to be fully laid out within the contract and communication strategy that both parties sign up to. All too often it is the ability of the contract to be interpreted differently by each party resulting in expensive legal battles as each party seeks redress and attempts to identify blame when projects go awry. Studies highlight that post mortems on large project failures that involve a contractor or consultant relationship often state that either the consultant did not have the skills to deliver the project or the consultant underestimated the complexity and scope of the project (Nawi et al. 2011, Verner and Abdullah 2012, Yeo 2002).

The project case histories as outlined in Brown and Jones (1998) and Warne and Hart (1997), highlight instances where the organizations concerned had either failed to formally prepare for change, were inexperienced in working with external organizations or had underestimated the impacts and complexities of large outsourced projects. These projects exhibited problems where difficulties were experienced in managing the contractor relationship with stakeholders not understanding the methods and approach of the contractor. These factors coupled with the intimidation felt by some stakeholders in their relationship with external organizations can further contribute to the failure of projects (Brown and Jones 1998, Warne and Hart 1997).

\section{Staff Turnover, Commitment, Motivation and Performance Issues}

Studies have identified that project failure has been influenced by the performance, commitment, turnover and motivation of staff with these issues becoming more apparent on long lead-time projects with dispersed teams across multiple geographic boundaries (Bussen and Myers 1997, Michie and West 2004, Newman and Sabherwal 1996, Rob 2003). The culture within technology-based organizations has for many years been one of staff working long hours as they struggle to develop and deliver a system to short timescales and unrealistic budgets leading to an eventual reduction in performance, increased cynicism and stress levels due to temporal dissonance (Conway and Limayem 2011, Verner et al 2008). Linberg (1999) reviewed a number of project failures from the practitioner perspective and highlight job satisfaction was not directly related to the motivation of staff to adhere to the meeting of timescales. The study raised the issues of excessive workload, individual and team temperament amongst developers and its potential to impact project outcomes both positively and negatively (Linberg 1999). Successful outcomes are better assured where organizations engender a team-based culture in which education and communication systems, people management and reward systems, are structured toward teams rather than individual staff (Michie and West 2004). 


\section{Poor Business Case, Objectives and Evaluation Stage}

The literature has identified a number of projects where failure can be associated with an unclear business case with poorly defined objectives highlighting the impact of not formalizing these deliverables and failing to define a realistic benefits management process (Sauer et al. 1997, Standing et al. 2006, Ward and Elvin 1999). The impact of not developing a fit for purpose business case during project initiation is the potential for carrying risk throughout the project leading to potential significant problems later in the lifecycle.

Organizations that have forged ahead with projects without undertaking proper product evaluation or feasibility have often suffered the consequences as these early lifecycle decisions become expensive to change later in the project. The ERP related studies of Barker and Frolick (2003) and Pan et al. (2008) highlight the issues where specific projects either did not undertake a product evaluation process or the evaluation processes followed was flawed leading to high levels of user resistance and a plethora of contributory failure factors.

\section{Inadequate Post Mortem Process}

Learning the lessons of past IS failures has been something that organizations, governments and the IS industry itself have been extremely slow to realize. Studies have identified industry trends where high numbers of projects have failed for similar reasons to previous failed projects within the same organization and that as few as 19\% of the organizations surveyed carried out a post-mortem on their projects (Ewusi-Mensah and Przasnyski 1995). These statistics are supported in Verner et al. (2008) where only a small number of the 304 surveyed organizations actually conducted post mortems and many of the organizations only conducted reviews of projects that were deemed to have been successful (Verner et al. 2008). This culture of hiding from post project audit and inability to learn the lessons of failure is a startling fact and runs counter to the key principle that lessons can be learned from each and every project regardless of the outcome (Kerzner 2013). The thorough analysis of organizations reluctance to consistently embrace post mortem processes on failed IS projects, is an area necessitating further research.

\section{Project management failure, why is it such a frequent factor given the increased levels of industry-wide professionalism?}

The project management industry has undergone a significant drive toward greater levels of professionalism over the last two decades or more. Certification routes for IS project management practitioners includes standards and methodologies such as PMP ${ }^{\circledR}$, PRINCE2 $^{\circledR}$ or one of the agile based methods such as DSDM or Scrum. The main practitioner bodies such as the Project Management Institute (PMI) and the Association for Project Management (APM) in the UK each have their own bodies of knowledge that underpin the standard within each organization. Practitioner certification in each of the main standards and methodologies involves the examination of the candidate's knowledge of the subject matter and application of the guidance in a project scenario context.

The $5^{\text {th }}$ edition of the PMBoK ${ }^{\circledR}$ published in PMI (2013) is an established project management standard organized around a number of key knowledge areas and required processes. The PMBoK ${ }^{\circledR}$ is not prescriptive, there are no detailed step-by-step instructions or methodology that set out the A-Z of how to manage a project. The standard details the required knowledge areas and expects the project manager to define or apply a suitable set of processes or methods to develop the main project structure. The $\mathrm{PMBoK}^{\circledR}$ explicitly states that the standard should not be seen as a methodology but as 
a good practice guide for project managers and directs practitioners toward methods such as PRINCE2 ${ }^{\circledR}$, agile or other methodological approaches (PMI 2013). The structure within PRINCE2 ${ }^{\circledR}$ is based on a number of key principles, themes and processes. The seven principles act as a overarching best practice framework for the management of the project such as: continued business justification and management by exception. The PRINCE2 ${ }^{\circledR}$ themes are the key project management areas for example plans, risk and quality that must be continually addressed throughout the project. The PRINCE2 ${ }^{\circledR}$ processes are the core activities needed to direct, manage and deliver a project. The tailoring principle within PRINCE2 ${ }^{\circledR}$ is key in that the method needs to be structured to fit the size and scope of the project to negate excessive management overhead and needless documentation (OGC Group 2013).

Organizations that incorporate a project management framework such as $\mathrm{PMBoK}^{\circledR}$ and the PRINCE $2^{\circledR}$ method are confronted with differences in approach, terminology and perspective that can raise issues in the application of the method within the framework. Each guidance prescribes alternative approaches to governance, organization structure, and approaches to stakeholder management. PRINCE2 ${ }^{\circledR}$ uses the term Project Initiation Document (PID) and stage, the PMBoK ${ }^{\circledR}$ uses the terms charter and phase to refer to the same deliverables and structure. Stakeholder management within the $\mathrm{PMBoK}^{\circledR}$, references the importance of: active listening, managing resistance, building trust and resolving conflict (PMI 2013), but the detail of how to manage these areas is omitted. It could be argued that the guidance in terms of the overall framework and the methodology, should be referencing external change management texts such as those in Hiatt and Creasey (2012), ACMP (2014) or CMI (2013) that provide the necessary detail on the complexities of assessing and managing user resistance, user adoption and sustaining change within the organization. PRINCE2 ${ }^{\circledR}$ does not include any guidance on the management of organizational political and cultural issues and specifically excludes some key areas of project management namely:

- Specialist products: procurement, organizational change management, software development methods and standards, and test management methods.

- Detailed techniques: planning and control techniques e.g. earned value and critical path analysis.

- Leadership capability: style and motivational aspects of leadership.

However, organizations that select PRINCE2 ${ }^{\circledR}$ as the methodology to help structure their project management may see the method as lacking if it does not include all the key elements to help them deliver successful projects. The literature has shown that projects have failed for a number of reasons (Al-Ahmad and Al-Fagih 2009, Bronte-Stewart 2009, Dwivedi et al. 2015b, Hughes et al. 2015) but a number of these key factors such as change management aspects, user resistance and adoption are explicitly omitted from the PRINCE2 ${ }^{\circledR}$ method without any external referencing to direct the project manager elsewhere.

The analysis of methodological approaches to IS project management and the applicability of standards and their suitability in delivering successful project outcomes, has not featured highly within academic studies. The existing literature in this area has been criticized as being narrow in focus or limited due to small sample size (Papke-Shields et al. 2010). The lack of academic focus on the practical application of PRINCE $2{ }^{\circledR}$ in particular reviewing the practical application of the method from the practitioner perspective is somewhat surprising given the wide use of the method especially within the context of the UK public sector. The IS failures as outlined in Beynon-Davies (1995), Fitzgerald and Russo (2005), McGrath (2002), Warne and Hart (1997) highlight significant failings but none of the studies question the application or use of the method. PRINCE2 ${ }^{\circledR}$ has been criticized by practitioners for the weaknesses of its risk management process, lacking sufficient detail in the estimation and impact of project risk (Elkington and Smallman 2002). The unwieldy nature of PRINCE $2^{\circledR}$ and its tendency for documentation overhead has also been criticized in studies (White and Fortune 2002), although the standard attempts to mitigate this by emphasizing the importance of 
tailoring the method to suit the application. Studies have highlighted that failed IS projects have either not used a project management methodology or that the one adopted was not applied correctly (Avison and Wilson 2002, Beynon-Davies 1995). The literature has tended to imply the use of a project management method or reference that modern project management techniques were used, but the analysis of any method and the approach taken in its implementation are not covered in the research (Gauld 2007, Mitev 1996, Pan et al. 2008, Verner and Abdullah 2012, Warne and Hart 1997). This theme continues in many studies where aspects of a methodology are discussed in the context of problems arising due to: requirements management or risk management but the application and suitability of the methodology itself is not covered (Dwivedi et al. 2013b, Heeks 2002, Keider 1974, Nelson 2007).

The emphasis on standards and certified project management practitioners has been a theme for a number of years within industry, however, if the ROI yields only negligible results, organizations must question their commitment and investment (Crawford 2005), especially in the context of organizations abilities to deliver large complex projects (Standish Group 2013). The instances of poor project management cited as one of the key reasons for project failure are numerous (Brown and Jones 1998, Emam and Koru 2008, Gauld 2007, Keil et al. 1998, Nawi et al. 2011, Pan et al. 2008) but the absence of sound analysis to ascertain if the failings are methodology based, experience or expertise driven or the individual approach and style of the project manager seems to be a gap in the research (Sauser et al. 2009, Söderlund 2011). The training and development of project managers generally tends to focus on the leading standards and such as PMBoK ${ }^{\circledR}$ or PRINCE2 ${ }^{\circledR}$ rather than taking a more actuality or people focus to successful project delivery. Perhaps a more inclusive, holistic emphasis of elements of social processes, collaborative working, learning and communication together with an understanding how practitioners actually function in the so-called swampy lowlands of projects (Winter et al. 2006ab) could benefit outcomes.

\section{Project success rates seem to be improving, what are the key reasons for this change in outcomes?}

The IS project success rates published in Standish (2013) highlight that between the years 2004 and 2012, projects categorized as successful were $29 \%$ and $39 \%$ respectively. This increasing trend demonstrates that organizations are slowly getting better at delivering projects, but highlights that a significant change is still required to bring success up to acceptable levels. The Standish (2013) report attributes the increase in success rates to a number of factors but highlights the change in competency of project sponsors as one of the key reasons (Standish 2013). The importance of good leadership, effective project sponsorship where success can be attributed to high levels of engagement and commitment to the role, are seen as key factors for success (Hiatt and Creasey 2012, Jugdev and Müller 2005, Patton and Shechet 2007, Young 2005). Effective and supportive project sponsorship is seen as the top contributor to success in a number of studies (Prosci 2012, 2014, Standish 2013, Keil et al. 1998) and is supported in the key practitioner standards (OGC Group 2013, PMI 2013) where reinforcing commitment and promoting project benefits are emphasized. The aspects of the literature that have analyzed the role and contribution of the project sponsor seem to agree on the fundamental importance of the role (Dwivedi 2015b, Kearns 2007), but many seem to rely on lists of relevant sponsorship activities and generally fail to explore the detail of the key areas of contribution to project success (Bryde 2008, Clarke 1999, Davis 2014, Marnewick 2012). From an actuality perspective, sponsors are often appointed by the executive not because they are the most suitable for the role, but possibly because they have the most availability or the project happens to be in their business area. It therefore, should not be a surprise that due to cultural and political considerations some potential sponsors may be reluctant to be associated with a project if they feel it may not end in success. This may result in middle managers taking up the role where a lack of organizational seniority results in inadequate resource allocation, budget approval and stakeholder commitment (Kerzner 2013). 
The Standish (2013) report also attributes the change in outcomes to the increasing skills of project managers, greater numbers of smaller projects, more agile based developments and better focus on project post mortems, although many organizations fail to standardize this process (Standish 2013). The change in emphasis from a somewhat inadequate reliance on the technical aspects of measuring outcomes (Atkinson 1999, Baker et al. 1983, de Wit 1988, Jugdev and Müller 2005, Sauer 1993, Shenhar et al. 2001), to a more stakeholder satisfaction soft skills oriented basis, has led to an increased focus on a more rounded skill-set for project managers. Successful projects are better assured where project managers can develop a skillset based on strategic client interaction and a combination of technical, managerial, motivational and positive leadership skills (Hyvari 2006, Sumner et al, 2006).

The performance of project managers has been heavily criticized within post mortem based studies of large and complex projects leading to an increased scrutiny of soft skills, cognitive style and analysis of the suitability and over reliance on the traditional skillset of project managers (Esa and Samad 2014, Scott and Vessey 2000). There seems to be a gradual realization within organizations that project outcomes are influenced by people factors as well as relevant technical and function aspects of project management (PMI 2013). Project success is linked with the personality traits of project managers and their ability to deal effectively with people; these skills need to be seen as equal contributors to project outcomes as the traditional - technical and process related attributes (Creasy and Anantatmula 2013, Lechler and Dvir 2010, Muller and Turner 2007, Sumner et al. 2006).

The literature has detailed the dire consequences of omitting to involve users at an early stage in the project, instances where projects suffered from poor stakeholder communication and the impact on organizations where the project failed to deal with high levels of user resistance (Barker and Frolick 2003, Beynon-Davies 1995, Fitzgerald and Russo 2005, Hirschheim and Newman 1988, Keil et al. 1998, McGrath 2002, Mitev 1996). Project success is influenced by the early engagement with stakeholders (PMI 2013) and a strategic focus on change management by the project and leadership teams. Presenting a clear vision of the proposed change and undertaking a process of persuasion via compelling arguments rather than brute force change is likely to lead to more positive outcomes (Cameron and Green 2012). Organizations demonstrating high levels of change management maturity with a structured approach to integrating change and project management are better able to deliver successful projects (Prosci 2012).

\section{Is there a case for the closer integration of change and project management to better assure project success?}

A significant body of knowledge has been developed within the separate fields of change and project management. However, the closer integration of these distinct disciplines has not featured highly within academic studies (Soderlund 2011). This fact seems somewhat surprising given that the outcomes of both change and project management are inextricably linked and failure of one is likely to lead to failure in the other. Some studies have referenced the need for closer integration in the context of the project management of organizational change initiatives (Oakland and Tanner 2007, Partington 1996), whilst separate studies have called for change initiatives to be structured as projects or highlighting the reliance that project success has on the approach to structured change management (Prosci 2014, Soderlund 2011). Project success relies on organizations recognizing the key benefits of a convergence of the two disciplines rather than separate functions within an organization each having different reporting lines and distinct deliverables (Ash 2007, Hornstein 2015, Parker et al. 2013).

The separate governing bodies and standards for change and project management together with their distinct certification paths with minimal referencing to the other discipline, different terminology, methodology and techniques (Kotter 1995), does not smooth the way to closer integration for the benefit of stakeholders. As each profession has developed it's own route to practitioner status and independent standards, this position has perhaps bred some confusion within organizations as sponsors debate why they need to procure two sets of competing practitioners each 
interacting with the same group of stakeholders (Jarocki 2011). The stakeholder perspective seems somewhat lost with the lack of an integration methodology between change and project management that clearly sets out the boundaries and interacting elements of what should be complementary methodologies. This picture varies depending on the level of change management maturity within an organization, however too often senior management are late off the starting blocks and suffer the consequences of considering change management aspects too late in the life project cycle (Hiatt and Creasy 2012).

It is widely accepted that change and project and managers have different skill sets and training needs but the distinct certification routes seem to pay little attention to the other discipline. The required high levels of interpersonal, political and sensitivity skills for major transformational projects do not feature highly in the traditional project management certification routes to practitioner status highlighting a potential skillset barrier in delivering successful outcomes (Cicmil et al. 2006, Crawford 2005, Crawford and Hassner-Nahmias 2010)

Methods to facilitate the closer integration of change and project management must be able to flex and adapt their processes depending on the levels of change maturity within the organization. Organizations demonstrating a culture not used to change or having a history of resistance to new project initiatives, would need to invest in structured approach to managing change that goes beyond the basic stakeholder communication guidance in most project management texts. Other organizations may be more used to frequent change and are further along the change maturity scale where resistance levels are low and stakeholders are comfortable with the process, terminology and outcomes. These types of organizations are not likely to need high levels of resistance mitigation techniques and extensive change management processes.

The success criteria for change and project management should ultimately be the same in that projects need to deliver their intended benefits and be adopted by stakeholders. Organizations need to focus on the critical people orientated, cultural, and adoption issues but of course must not lose sight of the required technical deliverables and key functionality (Hornstein 2015). The current inconsistent approach to how change and project practices are integrated within organizations, needs to be replaced with a structured integration methodology that removes the variable elements and provides a clear step by step approach to deliver successful outcomes. The analysis of how change and project management should integrate to provide the optimum chances of project success should be the subject of further academic study.

\section{Discussion}

IS failure in all its forms has been a subject of discussion and analysis for a number of years with an established academic body of literature that has attempted to make sense of this topic. Studies have contributed to this topic in a number of key areas of focus in particular the assessment and measurement of IS project failure. How we judge project failure is subjective (Dwivedi et al. 2013a, 2015a) but what is clear is that in instances where stakeholders cease to support a system irrespective of other factors, failure is highlight likely (Kerzner 2013, Sauer 1993). The framework set out in Figure 1 as developed in Hughes et al. (2015) and extended from Sauer et al. (1993), highlights the importance of stakeholder support for a system during the project period and importantly post delivery, as the full benefits are realized. Organizations that fail to invest in this phase of early operationalization are likely to see poor levels of adoption and potential reversion back to old working practices and procedures.

The literature has sought to identify the key reasons for IS failure with studies developing a taxonomy of factors associated with the failure of projects (Al-Ahmad and Al-Fagih 2009, Dwivedi et al. 2015b, Hughes et al. 2015). Separate studies have synthesized the key factors into a number of root causes of IS failure (Flowers 1997, Lyytinen and Hirschheim 1987, Pinto and Mantel 1990) providing further clarity on some of the core issues. Although the reasons for IS projects failing are many and varied: from poor requirements to user resistance issues, to poor executive support and so on, apart 
from listing these key areas, few studies provide further meaningful insight into the interrelationships between the factors. How failure factors are linked in terms their causal links between other factors and the potential for predictive association to be developed from these association seems to be a gap in the literature.

The failure of IS projects due to the performance and abilities of the project manager is a frequently cited cause of failure (Brown and Jones 1998, Emam and Koru 2008, Gauld 2007, Keil et al. 1998, Nawi et al. 2011, Pan et al. 2008). But are these project management failings due to the failings of the project managers skills, his lack of experience, the application of the selected methodology, errors in the decision making, lack of application of standards or inability to apply a more soft skills type approach with too high an emphasis on time cost and quality factors? The application and measurement of a more soft skills approach to project management is a key requirement for future successful project management (Kerzner 2015). Some studies have highlighted this gap in the literature emphasizing the importance of pursuing a deeper analysis to ascertain if these project management related failings are associated with management style, role and function (Sauser et al. 2009, Söderlund 2011) but many unanswered questions remain. The training and development of project managers generally tends to focus on the leading standards and methods such as PMBoK ${ }^{\circledR}$ or PRINCE2 ${ }^{\circledR}$ but do these provide the required levels of well-rounded skills to manage projects effectively? Is there a case for a greater emphasis on some of the key areas highlighted in the literature in the context of a retrospective of key problems or a more actuality or people focus to successful project delivery. In general, the literature has lacked a more holistic view of these areas and omitted elements of social processes, collaborative working, learning and communication together with an understanding how practitioners actually function in the so-called swampy lowlands of projects (Winter et al. 2006ab). A greater understanding of the intricacies and complexities of how project managers work in the real world away from the project management classroom, could be a useful addition to this genre of IS failure research.

There is some evidence that success rates for IS projects seem to be improving with recent studies highlighting a 10\% improvement in project outcomes Standish (2013). Although these Industrial based studies have been criticized for their lack of a published methodology (Emam and Koru 2008, Glass 2005), they do provide a useful indicator of overall trends. However, instances of large IS project failure are still ever present as the recent problems at the BBC with the failed DMI and e-borders projects testify, with total spend now exceeding $£ 950 \mathrm{~m}$ for both projects (BBC 2016a,b). Studies have highlighted that success rates have been influenced by an improvement in the competency of project sponsors (Standish 2013). The project sponsors responsibility of presenting a clear vision of the proposed change to the organization is of key importance with success better assured when this role is occupied by a fully committed and engaged senior executive (Keil et al. 1998, Prosci 2012, Standish 2013). In the modern world, leading stakeholders through a process of persuasion via compelling arguments is likely to lead to success rather than an ultimatum based, brute force approach (Cameron and Green 2012). However, the studies that have reviewed the role and contribution of the project sponsor, although demonstrating consistency on the fundamental importance of the role (Dwivedi 2015b, Kearns 2007), generally seem to have omitted to undertake any deeper analysis of these key areas of contribution to project success (Bryde 2008, Clarke 1999, Davis 2014, Marnewick 2012). Project success is cited as being heavily influenced by the style of project managers and their ability to deal effectively with people (Creasy and Anantatmula 2013, Lechler and Dvir 2010, Muller and Turner 2007, Sumner et al. 2006). The chances of a successful outcome are significantly increased when stakeholders are engaged early in the project lifecycle (PMI 2013). Countless studies have documented the impact of failing to do this effectively (Barker and Frolick 2003, Beynon-Davies 1995, Fitzgerald and Russo 2005, Hirschheim and Newman 1988, Keil et al. 1998, McGrath 2002, Mitev 1996).

Organizations demonstrating high levels of change management maturity with a structured approach to integrating change and project management are better able to deliver successful projects (Prosci 2012). Project success can be dependent on organizations understanding the benefits of a closer 
convergence of change and project management rather than separate functions within an organization (Ash 2007, Hornstein 2015, Parker et al. 2013). Organizations that accept the case for the greater integration of the two disciplines must be able to flex and adapt their processes based on their levels of change maturity. Organizations considering a more integrated approach to change and project management must retain focus on the key technical deliverables whilst demonstrating equal importance to the critical people related, cultural, and adoption factors (Hornstein 2015). The current practice of inconsistency of approach to how change and project practices are integrated within organizations is implicitly supported by the separate standards bodies and practitioners guidance (PMI

2013, CMI 2013). Successful project outcomes could be better assured with a formal integration methodology that removes the variable elements and provides a clear structured approach to deliver successful outcomes.

\section{Recommendations for Practitioners}

This study has developed a thorough analysis of the key factors surrounding the failure of IS projects. Many of these insights have implications for further academic study but also for practitioners. This section outlines many of these findings in the context of recommendations for practitioners:

- The research highlights that the failure of a large project is somewhat inevitable. Studies have recommended that organizations break up the project into smaller separate projects each with their individual business case, infrastructure and resource requirements with defined dependencies to align deliverables and key benefits.

- Projects that fail to learn the lessons of previous failures could be destined to repeat the same mistakes. Organizations must ensure that project post mortems form a key element of the project methodology.

- Studies have highlighted the critical importance of effective and engaged sponsorship and the impact on outcomes if the executive is not full committed to the project. Ensure the suitability and experience of the nominated sponsor is assessed at an early stage and work to bridge any gaps quickly.

- Learn to embrace the project audit process and not to resist the process. A well timed and thorough project audit carried out by experienced professionals can be invaluable and help to steer progress on the right path.

- Project managers will never have all the answers all of the time. Expect users to change their minds, plan for this and ensure the required controls are in place.

- Organizations cannot assume that the selection of a suitable project management methodology or set of standards will deliver a successful outcome. How the method or standards are applied is key, taking account of the wider aspects of organization culture and experience. Tailor the method to suit the project and organization.

- Expect users to change their minds, plan for this and ensure the controls are in place to manage this effectively.

- Do not use time, cost and quality as the measure of assessing the success of a project, the people related aspects are fundamental to benefit realization and cannot be ignored.

- There are a plethora of factors that are key to successful project delivery that do not feature in the methodology handbook or standards guidance. Do not underestimate the importance of experience and pragmatic application of project management to fit with the needs and cultural aspects of the organization.

- Assessing an organizations project and change management maturity is a vital early stage activity prior to the implementation of any methodology. 
- Unless the project takes steps to assess and understand stakeholder resistance early in the lifecycle, it is highly likely that key adoption and benefit realization related risks are carried through the project.

- Project and change management are separate disciplines with an immature integration methodology. Project managers must have sufficient knowledge and experience of change management principles and processes to ensure the project has the best chance of success.

\section{Limitations of Study and Recommendations for Future Study}

This study has explored many areas from the IS failure literature in an attempt to highlight the core topics and provide an insightful analysis of the key areas of research. This study is limited by its theoretical nature lacking an empirical element to provide a deeper analysis of IS failure factors and their interrelationships. This specific area is a recommendation for future research, where causal relationships between failure factors could be developed via a mathematic based method such as Interpretive Structural Modeling (ISM). This approach could provide underlying empirical support for the linking of factors and the potential for IS project failure. This area of research could be further extended to identify clear associations between failure factors specific to a methodology such as PRINCE $2^{\circledR}$ where the impact of links between factors are applied to specific stages of the project.

\section{Conclusions}

This study has attempted to provide an up to date review of the key aspects surrounding the analysis of IS failure and a taxonomy of some of the key factors that are seen as contributory causes. Studies have highlighted a number of key IS failure factors but gaps remain in the deeper analysis of associations between factors and how these can assist organizations in the predictive context of failure. The literature recognizes that rates of IS failure are still unacceptably high but success rates are slowly improving. The study analyzes some of the key areas within methodology, approach and application of change and project management that are attributed to these improving success rates. Poor project management seems to be a frequently cited cause of failed projects. Successful project managers are required to demonstrate a greater degree of soft skills than has traditionally been required to better assure successful outcomes. However, the key project management standards and methodologies do not seem to embrace this more holistic view of the discipline, demonstrating perhaps a gap between the guidance and the cold hard facts in the actuality of managing IS projects. This study recognizes the changing landscape and emphasis within project management with the trend in moving toward a more holistic view of successful outcomes based on business value (Hughes 2015, Kerzer 2013). Project managers are required to move outside of the traditional skillsets and accept that practitioners of the future need additional skills in leadership and business intelligence to deliver increasingly complex capabilities. (PMI 2016). Executives contemplating embarking on a project to deliver a new system or major transformation are faced with some fundamental decisions on how to deliver a project and address the change management requirements of the organization. The approach taken on how to integrate the change and project elements are fundamental decisions for senior management and can have a direct influence on project outcomes.

\section{References}

Association of Change Management Professionals ACMP. (2014) Standard for Change Management. FL. US.

Al-Ahmad, W., Al-Fagih, K. (2009), “A Taxonomy of an IT Project Failure: Root Causes”, International Management Review, Vol. 5, No.1, pp. 93-104. 
Ash, C (2007), "Convergence of it project management and change management: A comparative study". Proceedings of the European and Mediterranean Conference on Information Systems, Valencia, Spain, pp 1-8.

Atkinson, R (1999), "Project management: cost, time and quality, two best guesses and a phenomenon, its time to accept other success criteria”. International Journal of Project Management. Vol. 17, No. 6, pp. 337-342

Attarzadeh, I. Ow, S.H. (2008), "Project management practices: The criteria for success or failure". Communications of the IBIMA, Vol. 1, pp. 234-241.

Avison, D. Wilson, D. (2002), "IT failure and the collapse of One. Tel". Proceedings of the IFIP $17^{\text {th }}$ world computer congress - TC8 stream on information systems: the e-Business challenge, pp.31-46.

Avots, I. (1969). “Why Does Project Management Fail”? California Management Review, Vol. 12, No.1, pp. 77-82.

Baccarini, D. (1999). “The logical framework method for defining project success". Project Management Institute, Vol 30, No 4, pp. 25-30.

Baker, B.N, Murphy, D.C, Fischer, D. (1983), Factors affecting project success. In D. I. Cleland \& W. R. King (Eds.), Project management handbook. Van Nostrand Reinhold, New York, NY, pp 902-919.

Barker, T. and Frolick, M. (2003). "ERP Implementation Failure A Case Study”. Information Systems Management, Vol. 20, No 43-49.

Bartis, E. and Mitev, N. (2008), “A multiple narrative approach to information systems failure: A successful system that failed". Proceedings of the 15th European Conference on Information Systems, San Francisco, pp. 1421-1433.

BBC (2016a). Accessed on 01.01.2016. Home Office criticized over $£ 830 \mathrm{~m}$ 'failed' borders scheme http://www.bbc.co.uk/news/uk-34988913

BBC (2016b) Accessed on 01.01.2016 BBC was complacent over failed £100m IT project, http://www.bbc.co.uk/bbctrust/news/press_releases/2013/pwc_dmi.html

Beynon-Davies, P. (1995), "Information systems failure: the case of the London Ambulance services Computer Aided Despatch project”. European Journal of Information Systems, Vol 4, No. 3, pp. 171-184.

Brown, A. and Jones, M. (1998). "Doomed to Failure: Narratives of inevitability and conspiracy in a Failed IS Project". Organization Studies, Vol 19, No. 1, pp. 73-88.

Bronte-Stuart, M. (2009). "Risk Estimation From Technology Project Failure". In: $4^{\text {th }}$ European Conference on Management of Technology, Glasgow, Sept 2009.

Bryde, D. (2008). "Perceptions of the impact of project sponsorship practices on project success". International Journal of Project Management, Vol 26, No. 8, pp. 800-809.

Buchanan, D., Fitzgerald, L., Ketley, D., Gollop, R., Jones, J. L., Lamont, S.S., Neath, A., Whitby, E. (2005). “No going back: A review of the literature on sustaining organizational change". International Journal of Management Reviews, Vol 7, No. 3, pp. 189-205.

Bussen, W. and Myers, M. (1997), "Executive Information System Failure: A New Zealand Case Study". Journal of Information Technology, Vol 12, No. 2, pp. 145-153.

Cameron, E., Green, M. (2012), “Making Sense of Change Management”. $3^{\text {rd }}$ Edition. Kogan Page Ltd, London.

Cerpa, N. and J.M. Verner. (2009), "Why Did Your Project Fail”? Communications of the ACM, 2009. Vol 52, No. 12, pp 130-134.

Change Management Institute CMI (2013). "The Effective Change Manager: The Change Management Body of Knowledge (CMBoK), VIVID, Australia. 
Cicmil SJK., Williams, T., Thomas, J.L, Hodgson, D.E (2006), “Rethinking project management: researching the actuality of projects”. International Journal of Project Management, Vol 24, No 8, pp. 675-686.

Clarke, A (1999). "A practical use of key success factors to improve the effectiveness of project management". International Journal of Project Management, Vol 17, No. 3, pp. 139-145.

Conboy, K. (2010). "Project Failure en Mass: A Study of Loose Budgetary Control in ISD Projects". European Journal of Information Systems, Vol 8, No. 40, pp. 1-14.

Conway, C.M. and Limayem, M. (2011). "You want it when? How temporal dissonance in IT workers contributes to project failures". International Conference on Information Systems 2011, Shanghai.

Cooke-Davies T (2002), “The 'real' success factors on projects". International Journal of Project Management, Vol 20 No. 3, pp. 185-190.

Cooper, R.B, and Swanson, E.B. (1979). "Management Information Requirements Assessments: The State of the Art". ACM Sigmis DataBase, Vol 11, No. 2, pp. 5-16.

Crawford, L (2005), "Senior management perceptions of project management competence". International Journal of Project Management, Vol 23, No. 1, pp. 7-16.

Crawford, L, Hassner-Nahmias, AH. (2010). "Competencies for managing change". International Journal of Project Management, Vol 28, No. 4, pp. 405-412.

Creasy, T, Anantatmula, VS. (2013). "From every direction - How personality traits and dimensions of project managers can conceptually affect project success". Project Management Journal, Vol 44, No. 6, pp 36-51.

Cule, P., Schmidt, R., Lyytinen, K. and Keil, M. (2000). "Strategies for heading off IS project failure". Information Systems Management, Vol 17, No. 2, pp. 65-73.

Davis, K (2014). "Different Stakeholder Groups and their Perceptions of Project Success." International Journal of Project Management, Vol 32, No 2, pp. 189-201.

de Wit A (1988) “Measurement of project success”. International Journal of Project Management Vol 6, No. 3, pp. 164170 .

Dwivedi, Y.K., Henriksen, H.Z., Wastell, D. De’ RM, (2013a). Preface. In: Dwivedi YK et al (eds), “Grand successes and failures in IT: Private and public sectors". Springer, Berlin, pp 5-9.

Dwivedi YK., Ravichandran, K., Williams, M.D., Miller, S., Lal, B., Antony, G.V, Kartik, M. (2013b). "IS/IT project failures: A review of the extant literature for deriving a taxonomy of failure factors". In Dwivedi et al. (eds.) Grand successes and failures in IT. Public and private sectors, Springer, Berlin, Heidelberg, pp 73-88.

Dwivedi, Y.K., Wastell, D., Henriksen, H.Z (2015a) Guest editorial: “Grand successes and failures in IT: Private and public sectors”. Information Systems Frontiers, Vol 17, No. 1, pp. 11-14.

Dwivedi YK., Wastell, D., Laumer., S, Henriksen, H.Z, Myers, M.D, Bunker, D., Elbanna, A., Ravishankar, M.N., Srivastava, S.C (2015b) "Research on Information Systems Failures and Successes: Status Update and Future Directions”. Information Systems Frontiers Vol 17, No. 1, pp. 143-157.

Elkington, P., Smallman, C (2002). "Managing project risks: a case study from the utilities sector". International Journal of Project Management, Vol 20, No. 1, pp. 49-57.

El Emam, K and Koru, A. (2008). “A Replicated Survey of IT Software Project Failures”. Software, IEEE, pp. 84-90.

Esa M., Samad, Z (2014). "Preparing Project Managers to Achieve Project Success-Human Related Factor". International Journal of Resistance Management Technology, Vol 4, No. 2, pp. 104-110.

Ewusi-Mensah, K. (2003). "Software development failures: anatomy of abandoned projects". The MIT Press. pp. 45-64. 
Ewusi-Mensah, K. and Przasnyski, Z. (1995). "Learning from Abandoned Information systems development projects". Journal of Information Technology, Vol 10, pp. 3-14.

Fenech, K. and De Raffaele, C. (2013), “Overcoming ICT project failures - A practical perspective”. World Congress on Computer and Information Technology, Sousse.

Fitzgerald, G., and Russo, N.R. (2005). "The turnaround of the London ambulance service computer-aided despatch system (LASCAD)". European Journal of Information Systems, Vol 14, No. 3, pp. 244-257.

Flowers, S. (1997). "Information systems failure: Identifying the critical failure factors", Failure and Lessons

Learned in Information Technology Management, Vol 1, No. 1, pp. 19-29.

Glass, R.L (2005). "IT failure Rates - 70 percent or 10-15 percent”? IEEE Software, Vol 22, No. 3, pp. 110-112.

Gauld, R. (2007). "Public Sector Information System Failures: Lessons from a New Zealand hospital organization". Government Information Quarterly. Vol 24, pp. 102-114.

Goulielmos, M. (2005). "Applying the organizational failure diagnosis model to the study of information systems failure". Disaster Prevention and Management, Vol 14, No. 3, pp. 362-377.

Heeks, R. (2002). "Information Systems and Developing Countries: Failure, Success, and Local Improvisations". The Information Society, Vol 18, No 2, pp. 101-112.

Hiatt, J.M., Creasey, T.M. (2012), Change Management - “The People Side of Change”. Prosci Inc. Loveland, CO

Hirschheim, R. and Newman, M. (1988), "Information Systems and User Resistance: Theory and Practice". The Computer Journal, Volume 31, No. 5, pp. 398-408.

Hornstein, H. (2015), “The integration of project management and organizational change management is now a necessity". International Journal of Project Management, Vol 33, No. 2, pp. 291-298.

Hughes, D.1., Dwivedi, Y.K., Simintiras, A.C., Rana, N.P. (2015), Success and Failure of IS/IT Projects - A State of the Art Analysis and Future Directions. Springer. AG Switzerland.

Hyvari, I. (2006), "Success of Projects in Different Organizational Conditions”. Project Management Journal, Vol 37, No. 4, pp. 31-42.

Ika, L. (2009), "Project success as a topic in project management journals". Project Management Journal, Vol 40, No. 4, pp. 6-19.

Jarocki, T.L. (2011), "The next Evolution - Enhancing And Unifying Project and Change Management: The Emergence One Method For Total Project Success". Brown and Williams, Princeton, New Jersey.

Jones, C. (2004). "Software Project Management Practices: Failure Versus Success". The Journal of Defense Software Engineering, pp. 5-9.

Jones, C. (2006). "Social and technical reasons for software project failures". The Journal of Defense Software Engineering, Vol 19, No. 6, pp. 4-9.

Jugdev, K \& Müller, R. (2005), "Retrospective look at our evolving understanding of project success", Project Management Journal, Vol 36, No. 4, pp. 19.

Kearns, G.S. (2007), "How the internal environment impacts information systems project success: An investigation of exploitative and explorative firms". Journal of Computer Information Systems, Vol 48, No. 1, pp. 63-75.

Keider, S. (1974), “Why Projects Fail”. Datamation, Vol 20, No. 12, pp. 53-55.

Keil, M., Cule. P., Lyytinen, K., and Schmidt, R. (1998), "A framework for identifying software project risks". Communications of the ACM, Vol 41, No. 11, pp. 76-83. 
Kerzner, H. (2013), "Project Management. A Systems Approach to Planning, Scheduling and Controlling", 5" Edition, John Wiley and Sons, Hoboken, New Jersey.

Kerzner, H. (2015), “Project Management 2.0. John Wiley and Sons, Hoboken, New Jersey.

Klaus, T. and Blanton, J.E. (2010), "User resistance determinants and the psychological contract in enterprise system implementations". European Journal of Information Systems, Vol 19, No 6, pp. 625-636.

Kotter, J.P. (1995), “Leading Change: Why Transformation Efforts Fail”. Harvard Business Review Vol 73, No. 2, pp 5967.

Lechler, T.G, Dvir, D. (2010), “An alternative taxonomy of project management structures: Linking project management structures and project success”. IEEE Transactions on Engineering Management, Vol 57, No. 2, pp. $198-210$.

Lehtinen, T.O.A., Mäntylä, M.V., Vanhanen, J., Itkonen, J. and Lassenius, C. (2014), "Perceived causes of software project failures - An analysis of their relationships". Information and Software Technology, Vol 56, No. 6, pp. 623643.

Lemon, W.F., Liebowitz, J., Burn, J. and Hackney, R. (2002). Information systems project failure: A comparative study of two countries. Journal of Global Information Management, 10(2), pp. 28-39.

Linberg, K.R. (1999). Software developer perceptions about software project failure: A case study. Journal of Systems and Software, 49(2), pp. 177-192.

Lucas, H. (1975). Why information systems fail. Columbia, New York: University Press.

Lyytinen, K. and Hirschheim, R. (1987). Information Systems Failures: A survey and Classification of the Empirical literature. Oxford surveys in information Technology. 4(1), pp. 257-309.

March, J.G. and Olsen, J.P. (1977). Ambiguity and Choice in Organizations. Universitetsforlaget, Oslo.

Marnewick C (2012) A longitudinal analysis of ICT project success. ACM International Conference Proceeding Series, SAICSIT, SA, pp 326-334

McGrath, K. (2002). The Golden Circle: a way of arguing and acting about technology in the London Ambulance Service. European Journal of Information Systems, 11(4), pp. 251-266.

Michie, S. and West, M. (2004). Managing people and performance: an evidence based framework applied to health service organizations. International Journal of Management Reviews, 5(2), pp. 91-111.

Mitev, N.N. (1996). More than a failure ? The computerized reservation systems at French Railways. Information Technology \& People, 9(4), pp. 8-19.

Müller, R., Turner, J.R. (2007), "Matching the project manager's leadership style to project type”. International. Journal of Project Management. Vol 25, No. 1, pp. 21-32.

Nawi, H.S.A., Rahman, A.A. and Ibrahim, O. (2011), “Government's ICT project failure factors: A revisit”. International Conference on Research and Innovation in Information Systems, Kuala Lumpur.

Newman, M. and Sabherwal, R. (1996), "Determinants of Commitment to Information Systems Development: A Longitudinal Investigation”. MIS Quarterly, pp. 23-54.

Nelson, R. (2007). "IT Project Management: infamous failures, classic mistakes and best practices". MIS Quarterly Executive, Vol 6, No. 2, pp. 67-78.

Nixon, P., Harrington, M. and Parker, D. (2012), "Leadership performance is significant to project success or failure: a critical analysis”. International Journal of Productivity and Performance Management, Vol 61, No. 2, pp. $204-216$. 
Oakland, J., Tanner, S. (2007), "Successful Change Management.” Total Quality Management and Business Excellence, Vol 18, No. 1-2, pp. 1-19.

OGC Group. (2013), “Managing Successful Projects with Prince2”. London: TSO.

Pan, G., Hackney, R. and Pan, S.L. (2008), "Information Systems implementation failure: Insights from prism". International Journal of Information Management, Vol 28, No 4, pp. 259-269.

Papke-Shields, K.E, Beise, C, Quan, J. (2010), "Do project managers practice what they preach, and does it matter to project success"? International Journal of Project Management, Vol 28, No 7, pp. 650-662.

Parker, D., Charlton, J., Ribeiro, A, Pathak, R.D .(2013), "Integration of project-based management and change management - Intervention methodology". International Journal of Productivity and Performance Management, Vol 62, No. 5, pp 534-544.

Partington, D. (1996), “The project management of organizational change”. International Journal of Project Management Vol 14, No. 1, pp. 13-21.

Patton, N., Shechet, A. (2007), "Wisdom for building the project manager/project sponsor relationship: Partnership for project success". The Journal of Defense Engineering, Vol 20, No. 11, pp. 4-9.

Pettigrew, A. and Whipp, R. (1993), “Managing Change for Competitive Success”, Oxford: Black. pp. 269-295.

Perkins, T.K. (2006), "Knowledge: The core problem of project failure”, The Journal of Defense Engineering, Vol 19, No. 6, pp. 13-15.

Philip, T., Schwabe, G, Ewusi-Mensah, K. (2009), "Critical issues of offshore software development project failures". In ICIS 2009 Proceedings - Thirtieth International Conference on Information Systems. Phoenix, AZ.

Pinto, J.K. and Mantel, S.J. (1990). "The Causes of Project Failure”. IEEE Transactions on Engineering Management, Vol 37, No. 4, pp. 269-276.

PRINCE2 (2014). Website accessed October 2014. http://www.prince-officialsite.com/prince2-agile/prince2-agile.aspx

Project Management Institute PMI (2013). "A guide to the Project Management Body of Knowledge (PMBOK Guide)". Pennsylvania: PMI Inc.

Project Management Institute PMI (2016). Website accessed March 2016. http://www.pmi.org

Prosci, (2012), “Best Practices in Change Management”, Loveland: CO: Prosci.

Prosci, (2014), “Best Practices in Change Management”, Loveland: CO: Prosci.

Rob, M. (2003), Project failures in small companies. IEEE Software, Vol 20, No. 6, pp. 94-95.

Sauer, C. (1993). Why Information Systems Fail: A Case Study Approach. Oxford: Alfred Waller.

Sauer, C., Southon, G., and Dampney, C. (1997), "Fit, failure, and the house of horrors: toward a configurational theory of IS project failure". Proceedings of the eighteenth International Conference on Information Systems ICIS, Atlanta, pp. 349-366.

Sauser, J., Reilly, R.R., Shenhar, A.J. (2009), "Why projects fail? How contingency theory can provide new insights - A comparative analysis of NASA's Mars Climate Orbiter loss”. International Journal of Project Management, Vol 27, No. 7, pp. 665-679.

Schmidt, R., Lyytinen, K., Keil, M. and Cule, P. (2001), "Identifying software project risks: an international Delphi study". Journal of management Information Systems, Vol 17, No. 4, pp. 5-36.

Shenhar, A., Dvir, D, Levy O., Maltz, A. (2001), "Project success: a multidimensional strategic concept". Long Range Planning Vol 34, No. 201, pp. 699-725. 
Scott, J. and Vessey, I. (2000), "Implementing enterprise resource planning systems: the role of learning from failure". Information systems frontiers, Vol 2, No. 2, pp. 213-232.

Söderlund, J. (2011), "Pluralism in project management: navigating the crossroads of specialization and fragmentation". International Journal of Management Reviews, Vol 13, No. 2, pp. 153-176.

Standing, C., Guilfoyle, A., Lin, C. and Love, P.E.D. (2006), "The attribution of success and failure in IT projects". Industrial Management and Data Systems, Vol 106, No. 8, pp. 1148-1165.

Standish Group. (2013), “CHAOS Manifesto. Think Big Act Small”. Boston.

Sumner, M., Bock, D, Giamartino, G. (2006), "Exploring the linkage between the characteristics of it project leaders and project success". Information Systems Management Vol 23, No. 4, pp. 43-49.

Tukel, O.I. and Rom, W.O. (1998), "Analysis of the characteristics of projects in diverse industries". Journal of Operations Management, Vol 16, No. 1, pp. 43-61.

Verner, J.M. and Abdullah, L.M. (2012), "Exploratory case study research: Outsourced project failure". Information and Software Technology, Vol 54, No. 8, pp. 866-886.

Verner, J., Sampson, J. and Cerpa, N. (2008), "What factors lead to software project failure"? Proceedings of the 2nd International Conference on Research Challenges in Information Science, pp. 71-79.

Wallace, L., Keil, M. and Rai, A. (2004). "Understanding software project risk: a cluster analysis". Information \& Management, Vol 42, No. 1, pp. 115-125.

Ward, J., Elvin, R. (1999), “A new framework for managing IT-enabled business change”. Information Systems Journal, Vol 9, No. 3, pp. 197-221.

Warne, L. and Hart, D. (1997), "Organizational politics and project failure: A case study of a large public sector project". Failure and Lessons Learned in Information Technology Management Vol 1, No. 1, pp. 57-65.

White, D, Fortune J (2002), “Current Practice in project management - an empirical study". International Journal of Project Management Vol 20, No. 1, pp. 1-11.

Winklhofer, H. (2001). "Organizational change as a contributing factor to IS failure". Proceedings of the Hawaii International Conference on System Sciences, Hawaii, pp. 232.

Winter, M., Smith, C., Morris, P., Cicmil, S. (2006a), "Directions for future research in project management: The main findings of a UK government-funded research network”. International Journal of Project Management, Vol 24, No. 8, pp. 650-662.

Winter, M., Smith, C., Cooke-Davies, T., Cicmil. S. (2006b), "The importance of 'process' in Rethinking Project Management: The story of a UK Government -funded research network". International Journal of Project Management Vol 24, No. 8, pp. 638-649.

Yeo, K,T. (2002), “Critical failure factors in information system projects”. International Journal of Project Management, Vol, 20, No. 3, pp. 241-246.

Young, R. (2005). “An example of relevant IS research for top managers on IT project failure”. ACIS 2005 Proceedings 16th Australasian Conference on Information Systems. Sydney, pp. 14. 